\title{
Paweł ŚCIGAJ
}

Uniwersytet Jagielloński

pawel.scigaj@uj.edu.pl

\section{CO Z NAMI BĘDZIE?}

\section{STUDIA POLITOLOGICZNE I NA KIERUNKACH POKREWNYCH W PERSPEKTYWIE 2020 R.}

ABSTRACT What will become of us? Studies in political science and related fields in 2020 perspective

Dynamic increase in the number of students was one of the most significant process in higher education after 1989 in Poland, very well seen in humanities and social sciences programs of studies, especially in political science. It is worth to mention that there were 4 thousand students of political science in academic year 1990/91, and till the academic year of 2004/05 the number increased and reached near 56 thousand, and then it started to fall rapidly to 10 thousand in $2014 / 15$. At the same time due to demographic crisis and decreasing number of 19-year-olds there have been fewer candidates to study in general, including political science. Similar processes has been observed also in related fields, such as international relations, security studies, journalism and social communication, and European studies. The article is an attempt to present predictions of future changes in the number of political studies students' population till the year 2020, together with the possible consequences of this state of affairs for political science and related fields.

Słowa kluczowe: nauka o polityce, studia wyższe, studenci politologii

Keywords: political science, higher education, political science students 
WV 2011 r. eksperci Instytutu Sokratesa trafnie pisali: [...] trend demograficzny, który byt motorem napędowym rozwoju szkolnictwa wyższego przez większość okresu transformacji, nie tylko skończyt się, ale zacząt gwattownie się odwracać. Zmienia to niemal catkowicie sytuacjępolskiego szkolnictwa wyższego, a gtęboki niż demograficzny powoduje, że duża część uczelni, zwtaszcza niepublicznych, znajdzie się wniezwykle trudnej sytuacji ${ }^{1}$.

Aby zobrazować powyższe przekonanie, autorzy podali szereg danych liczbowych wraz z możliwymi scenariuszami dalszych zmian - żadnego z nich nie można uznać za optymistyczny. Bez względu na szczegółowe przewidywania co do głębokości i intensywności zmian wnioski były podobne: likwidacja uczelni (głównie niepublicznych), nieuruchamianie kierunków studiów, możliwe obniżanie jakości kształcenia jako efekt „walki o studenta” i potencjalne zwolnienia pracowników naukowo-dydaktycznych ${ }^{2}$. Wszystko to ma mieć jedną podstawową przyczynę - widoczny coraz wyraźniej na uczelniach wyższych niż demograficzny.

Dobrze znane są przewidywania na temat liczby studentów w Polsce w kolejnych latach. Niewiele jednak jest prognoz, które dotyczyłyby konkretnych kierunków studiów. Warto więc zadać pytanie, jak owe zmiany, w postaci zmniejszającej się liczby młodych osób mogących podjąć edukację na uczelniach wyższych, wpłynąć mogą na kierunek studiów politologia oraz kierunki pokrewne. To jest właśnie cel niniejszego artykułu: przedstawienie obecnej sytuacji na studiach politologicznych i kierunkach pokrewnych oraz próba zarysowania niektórych prawdopodobnych scenariuszy dalszych zmian. Aby tego dokonać, przypomnę pewne podstawowe dane demograficzne odnośnie do liczby potencjalnych kandydatów na studia oraz studentów w Polsce, następnie pokażę tendencje rozwojowe kierunku politologia oraz kierunków pokrewnych w postaci zmian liczby studentów, a na końcu przedstawię możliwe scenariusze dalszego rozwoju owych kierunków studiów ${ }^{3}$.

\footnotetext{
D. Antonowicz, B. Gorlewski, Demograficzne tsunami. Raport Instytutu Sokratesa na temat wptywu zmian demograficznych na szkolnictwo wyższe do 2020 roku, Warszawa 2011, s. 2, [online] http://instytutsokratesa.pl/pliki/Demograficzne_Tsunami_Instytut_Sokratesa.pdf, 30 VI 2015.
}

2 Tamże, s. 17-18. Podobnego zdania są eksperci przygotowujący inne raporty na temat kondycji i przyszłości szkolnictwa wyższego w Polsce: Strategia rozwoju szkolnictwa wyższego w Polsce do 2020 rokudrugi wariant, Raport cząstkowy przygotowany przez konsorcjum Ernst\&Young Business Advisory oraz Instytut Badań nad Gospodarką Rynkową, marzec 2010, s. 21-22, 37-39, [online] http://www. nauka.gov.pl/g2/oryginal/2013_05/59579f9e6efaec82014d6d5be081ca23.pdf, 2 VII 2015; Diagnoza stanu szkolnictwa wyższego w Polsce, Raport cząstkowy przygotowany przez konsorcjum Ernst\& Young Business Advisory oraz Instytut Badań nad Gospodarką Rynkową, listopad 2009, s. 39-40, [online] http://www.nauka.gov.pl/g2/oryginal/2013_05/fa5b19e372e1bed45db817b8380c8468.pdf, 2 VII 2015; Strategia rozwoju szkolnictwa wyższego 2010-2020. Projekt środowiskowy, Warszawa 2009, s. 32-33, [online] http://www.krasp.org.pl/pliki/fdc2bf4809b691e28546a48f8451c42f.pdf, 2 VII 2015.

3 Należy jeszcze dodać, że zaprezentowane tu dane oraz możliwe scenariusze dalszych zmian są oparte głównie na szeroko dostępnych danych statystycznych publikowanych przez Główny Urząd Statystyczny oraz inne instytucje publiczne. Szczegółowe źródła będą przedstawiane w odpowiednich momentach analizy. Ponadto zaprezentowane tu rozważania są kontynuacją badań nad kondycją polskiej 


\section{„POD WPEYWEM NIŻU” - STUDIA WYŻSZE WOBEC ZMIAN DEMOGRAFICZNYCH}

Wypada rozpocząć od przypomnienia pewnych podstawowych trendów demograficznych oraz prognoz na lata kolejne. I tak, w roku 2002 było w Polsce ponad 692 tys. osób w wieku 19 lat oraz ok. 3,9 mln osób w wieku 19-24, który jest w statystykach przedstawiany jako wiek nominalnie przypisany do edukacji na studiach wyższych. W roku 2010 populacje te zmniejszyły się do odpowiednio ok. 534 tys. oraz ok. 3,4 mln osób ${ }^{4}$. W kolejnych latach grupa dziewiętnastolatków będzie co roku mniejsza o ok. 10-20 tys. i spadnie do poziomu ok 366 tys. w roku 2020. Dane szczegółowe prezentuje wykres 1.

Mając to na względzie, kwestią szczególnie ważną jest prognozowana liczba studentów w roku akademickim 2020/2021. Według autorów raportu Demograficzne tsunami spadnie ona do ok. 1250 tys. (przy założeniu, że współczynnik skolaryzacji brutto będzie wynosił 54\%) $)^{5}$, a więc do poziomu odpowiadającemu wielkości zbiorowości studentów uczelni publicznych $\mathrm{w}$ roku $2009 / 2010^{6}$. Bardziej optymistyczne są dane prezentowane przez OECD, gdzie przewiduje się w 2020 r. odpowiednio 1327 tys. studentów w Polsce, przy założeniu, że odsetek przyjętych na studia spośród grupy do tego nominalnie przypisanej będzie analogiczny jak w roku 2004, lub nawet 1482 tys., biorąc pod uwagę trendy wzrostowe w zakresie odsetka przyjętych na studia spośród grupy do tego nominalnie przypisanej. Co interesujące, $w$ każdym przypadku spadki liczby studentów będą w Polsce największe, gdy idzie o skalę, spośród wszystkich poddawanych badaniu krajów OECD ${ }^{7}$. Także Ministerstwo Nauki i Szkolnictwa Wyższego przedstawiło swoje prognozy w tym zakresie. I tak, według przewidywań MNiSW w Polsce powinno być: 1502 tys. studentów w roku akademickim 2015/2016, 1451 tys. w roku akademickim 2016/2017, 1406 tys. w roku akademickim 2017/2018, 1364 tys. w roku akademickim 2018/2019, 1332 tys. w roku akademickim 2019/2020 oraz 1305 tys. w roku akademic-

politologii podjętych przez zespół pod kierownictwem Barbary Krauz-Mozer: zob. ciż, Kim jesteś, politologu? Historia $i$ stan dyscypliny w Polsce, t. 1-2, Kraków 2011-2012; ciż, Political Science in Poland within 1989-2009. Applicants, Students and Graduates of Political Studies, „Athenaeum” 2011, nr 30, s. 7-30; ciż, The Condition and Perspectives of Political Science in the Beginning of the 21st Century, [w:] Political Science in Europe at the Beginning of the 21st Century, red. B. Krauz-Mozer i in., Kraków 2015 [w druku].

4 D. Antonowicz, B. Gorlewski, Demograficzne tsunami..., s. 8.

5 Zgodnie z definicjami stosowanymi przez GUS: wspótczynnik skolaryzacji brutto jest to wyrażony procentowo stosunek liczby wszystkich osób uczacych się na danym poziomie do catej populacji osób będących $w$ wieku nominalnie przypisanym temu poziomowi ksztatcenia (w przypadku szkolnictwa wyższego 19-24 lata (wedtug stanu w dniu 31 grudnia)). Wspótczynnik skolaryzacji netto to stosunek (również wyrażony procentowo) liczby osób uczących się w nominalnym wieku ksztatcenia na danym poziomie do catej populacji osób będacych w wieku normalnie przypisanym temu poziomowi ksztatcenia. Szkoty wyższe i ich finanse w 2013 roku, Główny Urząd Statystyczny, Warszawa 2014, s. 29.

6 Tamże, s. 10.

Higher Education to 2030, vol. 1: Demography, OECD Publishing, 2008, s. 45-48, [online] http:// www.oecd.org/edu/ceri/41939423.pdf, 2 VII 2015. 
kim 2020/2021 ${ }^{8}$. Biorąc pod uwagę fakt, że w latach 2004-2009 liczba studentów w Polsce przekraczała 1,9 mln osób, nadchodzące spadki wydają się znaczące.

Wykres 1. Prognoza liczby dziewiętnoastolatków w latach 2011-2020

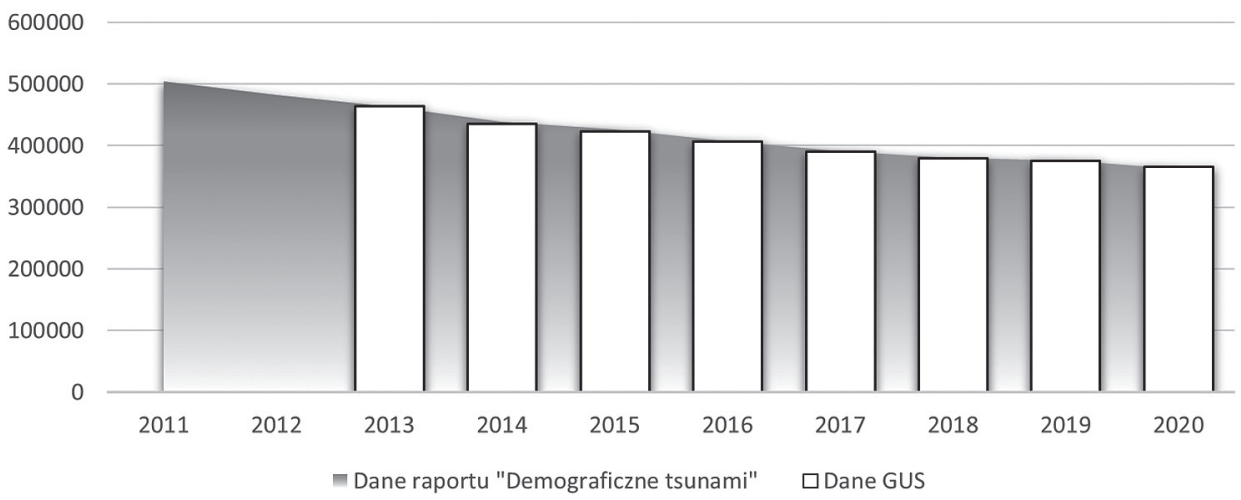

Źródło: opracowanie własne na podstawie: D. Antonowicz, B. Gorlewski, Demograficzne tsunami. Raport Instytutu Sokratesa na temat wptywu zmian demograficznych na szkolnictwo wyższe do 2020 roku, Warszawa 2011, s. 8, [online] http://instytutsokratesa.pl/pliki/Demograficzne_Tsunami_Instytut_Sokratesa.pdf, 30 VI 2015; Prognoza ludności na lata 2014-2050 - Polska, Główny Urząd Statystyczny, [online] http:// demografia.stat.gov.pl/bazademografia/Prognoza.aspx, 2 VII 2015.

Ostatnie lata przyniosły również, jak się zdaje, odwrócenie widocznego od początku lat $90 . \mathrm{XX}$ w. procesu rosnącej popularności studiów wyższych. O ile bowiem przez 20 lat po przełomie politycznym w Polsce współczynniki skolaryzacji brutto i netto stale rosły, o tyle począwszy od roku 2011, zaczęły maleć do poziomu 49,2\% dla współczynnika skolaryzacji brutto oraz do $38,6 \%$ dla współczynnika skolaryzacji netto. Dane prezentuje tab. 1.

Tabela 1. Współczynnik skolaryzacji brutto i netto w latach 1990-2013

\begin{tabular}{|l|c|c|c|c|c|c|c|c|}
\hline & 1990 & 1995 & 2000 & 2005 & 2010 & 2011 & 2012 & 2013 \\
\hline Brutto & 12,9 & 22,3 & 40,7 & 48,9 & 53,8 & 53,1 & 51,8 & 49,2 \\
\hline Netto & 9,8 & 17,2 & 30,6 & 38 & 40,8 & 40,6 & 40,2 & 38,6 \\
\hline
\end{tabular}

Źródło: Szkoty wyższe i ich finanse w 2013 roku, Główny Urząd Statystyczny, Warszawa 2014, s. 30.

Powyższe dane skłaniają do ostrożnego wniosku, że malejąca liczba studentów jest konsekwencją nie tylko mniej licznych roczników dziewiętnastolatków, spośród których rekrutuje się większość rozpoczynających edukację wyższą, ale także możliwego spadającego zainteresowania studiami wyższymi?.

8 Szkolnictwo wyższe w Polsce, 2013, Ministerstwo Nauki i Szkolnictwa Wyższego, s. 8, [online] http:// www.nauka.gov.pl/g2/oryginal/2013_07/0695136d37bd577c8ab03acc5c59a1f6.pdf, 2 VII 2015.

9 Oczywiście nie ma mocnych dowodów na takie przekonanie, jednak pewnym argumentem na rzecz takiego stanowiska jest fakt, że o ile na rok akademicki 2012/2013 na uczelnie wyższe nadzorowane 


\section{POLITOLOGIA I KIERUNKI POKREWNE W LATACH 1990-2014 10}

Nie jest dziś kwestią nową twierdzenie, że studia politologiczne przeżywały gwałtowne zmiany, gdy idzie o liczbę studentów, na przestrzeni ostatnich 25 lat. Jeszcze w roku akademickim 1990/1991 było w Polsce ok. 4 tys. studentów politologii, jednak na przestrzeni kolejnych lat liczba ta zaczęła bardzo szybko rosnąć, osiągając szczyt w roku akademickim 2004/2006 w postaci blisko 56 tys. studentów i pozostając na podobnym poziomie przez kolejne dwa lata. Począwszy od roku akademickiego 2007/2008, obserwujemy gwałtowny spadek liczby studentów politologii w Polsce, i to bez względu na rodzaj uczelni, tryb studiów oraz stopień kształcenia. Wielkości owych spadków są znaczące - do dziś populacja studentów politologii w Polsce kurczy się nieustannie o ok. 5-6 tys. osób rocznie. Według danych Głównego Urzędu Statystycznego w roku akademickim 2014/2015 politologię studiowało w Polsce ledwie 10406 osób, co oznacza, że na przestrzeni ośmiu lat zniknęło ze studiów politologicznych 45 tys. żaków! Krótko mówiąc, nowo wstępujące na uczelnie wyższe roczniki studentów politologii są znacząco mniej liczne aniżeli każdy niemal rocznik wcześniejszy, co sprawia, że populacja politologów od ośmiu lat się nie odtwarza, lecz kurczy z roku na rok ${ }^{11}$. Szczegółowe dane prezentuje wykres 2 .

przez MNiSW przyjęto blisko 550 tys. osób, o tyle dwa lata później - na rok akademicki 2014/2015 przyjęto już tylko nieco ponad 460 tys. osób (ważne, by pamiętać, że wielkości te nie odnoszą się do osób jako takich, lecz do liczby zarejestrowanych na studia, przy założeniu, że jedna osoba może się zarejestrować na wiele kierunków). Jednocześnie liczba dziewiętnastolatków według autorów raportu Demograficzne tsunami zmniejszyła się w tym czasie w Polsce o ok. 40 tys. osób. Nie bez znaczenia pozostawał fakt wprowadzenia odpłatności za drugi kierunek studiów, niemniej i to nie pozwala zrozumieć, dlaczego po zniesieniu odpłatności na rok akademicki 2014/2015 nie nastąpił wzrost przyjęć w stosunku do roku akademickiego 2013/2014 (wówczas wynosił on blisko 477 tys. osób). Wydaje się, że spadki zarówno współczynnika skolaryzacji brutto, jak i netto mogą sugerować zmniejszające się zainteresowanie studiami w Polsce, i to zarówno wśród dziewiętnastolatków, jak i osób, które będąc $\mathrm{w}$ wieku nominalnie nieprzypisanym do poziomu kształcenia, podejmowały studia. Idzie tu rzecz jasna głównie o osoby starsze, studiujące na studiach niestacjonarnych. D. Antonowicz, B. Gorlewski, Demograficzne tsunami..., s. 8; Informacja o wynikach rekrutacji na studia na rok akademicki 2012/2013 w uczelniach nadzorowanych przez Ministra Nauki i Szkolnictwa Wyższego, [online] https://www.nauka.gov.pl/g2/oryginal/2013_11/01e458dfe708774d43130e085402f03a.doc, 2 VII 2015; Informacja o wynikach rekrutacji na studia na rok akademicki 2013/2014 w uczelniach nadzorowanych przez Ministra Nauki i Szkolnictwa Wyższego, [online] http://www.nauka.gov.pl/g2/orygina1/2013_05/2c9dcb54750b1bea5b1e3c22cad6f20a.pdf, 2 VII 2015; Informacja o wynikach rekrutacji na studia na rok akademicki 2014/2015 w uczelniach nadzorowanych przez Ministra Nauki i Szkolnictwa Wyższego, [online] http://www.nauka.gov.pl/g2/oryginal/2014_11/b34c7353d34b2c9a42ee14aa2b005e27.pdf, 2 VII 2015.

10 Dane oraz analizy odnoszące się do lat 1990-2011 przedstawione w tej części powstały w ramach realizacji projektu badawczego zespołu pod kierownictwem Barbary Krauz-Mozer. Lista publikacji została przedstawiona w przyp. 3 .

11 Szczegółowe analizy dotyczące możliwych przyczyn tego procesu zawarte są w: B. Krauz-Mozer, P. Borowiec, P. Ścigaj, Kim jesteś, politologu?..., t. 1, s. 174-202, 260-266. 
Wykres 2. Studenci politologii w latach 1990-2014

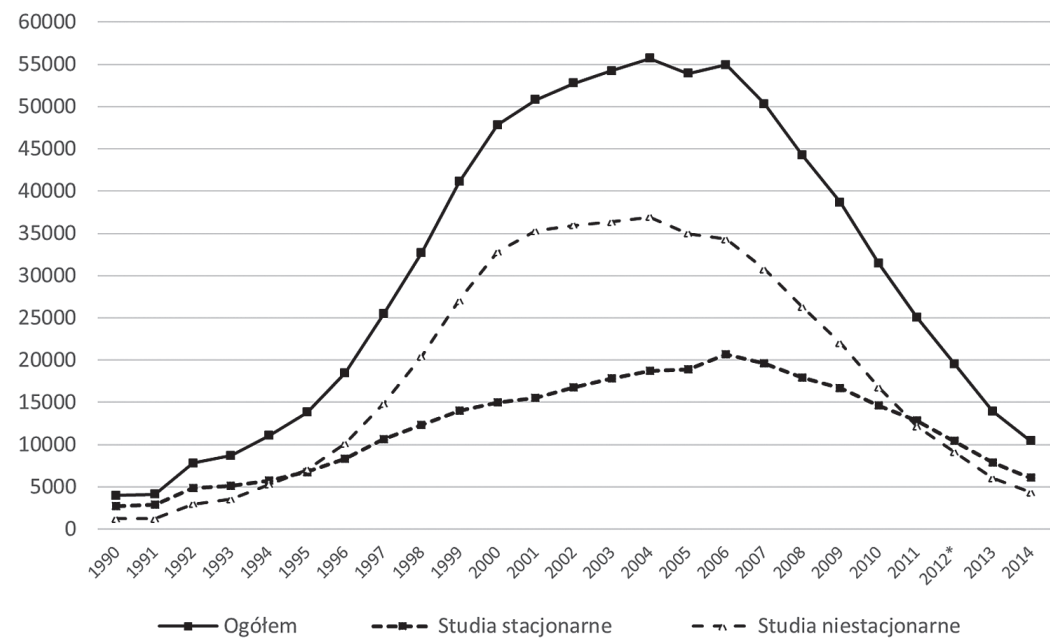

* Dane szacunkowe ze względu na brak danych za rok 2012.

Uwaga! W tym i w kolejnych wykresach rok podany na wykresie jest odpowiednikiem dla roku akademickiego, tzn. rok 2005 oznacza rok akademicki 2005/2006, rok 2006 oznacza rok 2006/2007 itd.

Dane dla studiów niestacjonarnych w latach 1990-2004 obejmują studia zaoczne, wieczorowe i eksternistyczne.

Źródło: opracowanie własne na podstawie: Szkolnictwo wyższe. Dane podstawowe, Główny Urząd Statystyczny, Warszawa [1990-2011], Dane wstępne dotyczące szkolnictwa wyższego - 2013, [online] http:// stat.gov.pl/obszary-tematyczne/edukacja/edukacja/dane-wstepne-dotyczace-szkolnictwa-wyzszego-stan-w-dniu-30-xi-2013-r-,8,1.html, 20 VI 2015; Dane wstępne dotyczace szkolnictwa wyższego - 2014, [online] http://stat.gov.pl/obszary-tematyczne/edukacja/edukacja/dane-wstepne-dotyczace-szkolnictwa-wyzszego-2014-r-,8,2.html, 20 VI 2015.

Powyższe procesy dotykają nie tylko politologię, ale także kierunki pokrewne ${ }^{12}$. $\mathrm{Na}$ potrzeby tego artykułu do grupy kierunków pokrewnych zaliczam: bezpieczeństwo $^{13}$, dziennikarstwo i komunikację społeczną ${ }^{14}$, europeistykę ${ }^{15}$ oraz stosunki między-

12 Kryteria wyboru powyższych kierunków studiów są następujące: po pierwsze, wszystkie one należą do obszaru nauk społecznych i dziedziny nauk społecznych, po drugie, w niektórych raportach Państwowej Komisji Akredytacyjnej są one zaliczane do grupy kierunków pokrewnych, po trzecie, wiele jednostek prowadzących politologię w Polsce uruchomiło także studia na tych kierunkach.

13 Spośród wszystkich prowadzonych na polskich uczelniach kierunków do grupy studiów w zakresie bezpieczeństwa na przestrzeni lat 2009-2015 zaliczono: bezpieczeństwo narodowe, bezpieczeństwo wewnętrzne, bezpieczeństwo międzynarodowe, bezpieczeństwo jądrowe, bezpieczeństwo w biznesie i administracji, bezpieczeństwo państwa, bezpieczeństwo narodowe i międzynarodowe.

14 Spośród wszystkich prowadzonych na polskich uczelniach kierunków do grupy studiów w zakresie dziennikarstwa i komunikacji społecznej na przestrzeni lat 2000-2015 zaliczono: dziennikarstwo, dziennikarstwo i komunikację społeczną, dziennikarstwo i komunikację medialną, dziennikarstwo i public relations.

15 Spośród wszystkich prowadzonych na polskich uczelniach kierunków do grupy studiów w zakresie europeistyki na przestrzeni lat 2000-2015 zaliczono: europeistykę, integrację europejską, stosunki gospodarcze Unii Europejskiej, europeistyczne studia historyczno-filozoficzne, międzynarodową współpracę i integrację europejską, europeistyczne studia filozoficzno-historyczne. 
narodowe ${ }^{16}$. Lista ta, rzecz jasna, mogłaby być dłuższa, obejmując choćby psychologię, socjologię, administrację, ekonomię czy inne jeszcze kierunki z obszaru nauk społecznych, jednak nie wydaje mi się to celowe. Powyższe cztery kierunki pokrewne są najbliższe politologii tak pod względem przedmiotowym, jak i kadrowym, o czym świadczy choćby fakt, że są one często prowadzone w ramach tych samych jednostek organizacyjnych uczelni wyższych.

Tendencje rozwojowe kierunków pokrewnych dla politologii są podobne, choć różnią je dynamika oraz okres największej popularności. I tak, o ile dla politologii czas największego zainteresowania kandydatów przekładający się na znaczny przyrost liczby studentów przypadał na lata 2004-2006, o tyle dla stosunków międzynarodowych były to lata 2005-2008, dla dziennikarstwa i komunikacji społecznej lata 2009-2011, dla europeistyki lata 2008-2009, zaś dla bezpieczeństwa okres dynamicznego wzrostu rozpoczą się od roku akademickiego 2009/2010 i trwał nieprzerwanie aż do roku akademickiego 2013/2014. Szczegółowe dane prezentuje wykres 3.

Wykres 3. Studenci politologii oraz kierunków pokrewnych w latach 2010-2014

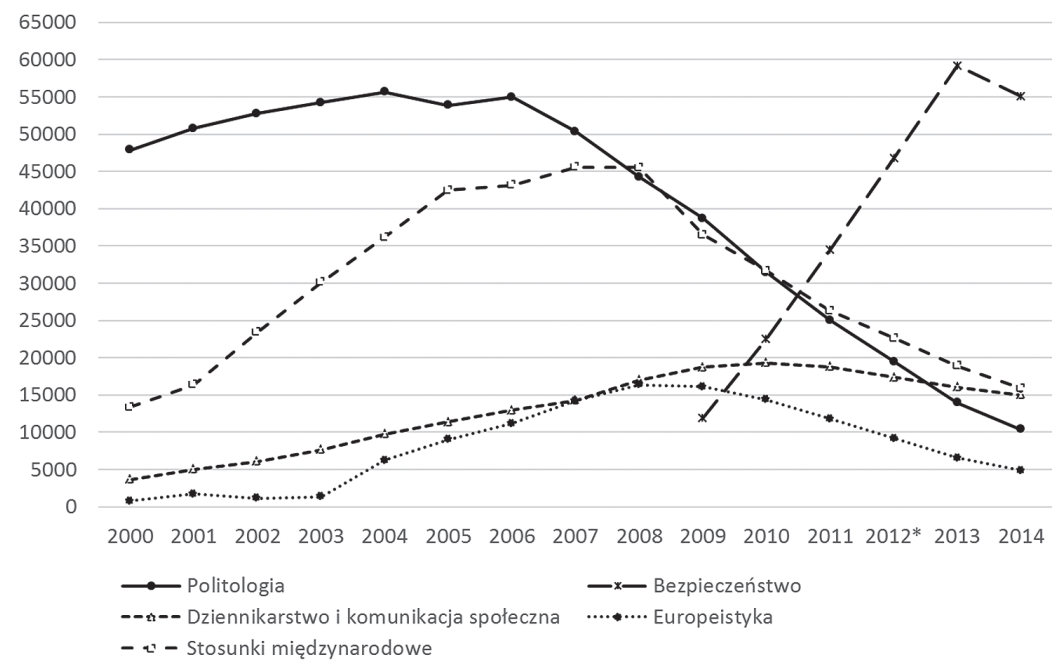

${ }^{*}$ Dane szacunkowe ze względu na brak danych za rok 2012.

Źródło: opracowanie własne na podstawie: Szkolnictwo wyższe. Dane podstawowe, Główny Urząd Statystyczny, Warszawa [2000-2011], Dane wstępne dotyczące szkolnictwa wyższego - 2013, [online] http:// stat.gov.pl/obszary-tematyczne/edukacja/edukacja/dane-wstepne-dotyczace-szkolnictwa-wyzszego-stan-w-dniu-30-xi-2013-r-,8,1.html, 20 VI 2015; Dane wstępne dotyczace szkolnictwa wyższego - 2014, [online] http://stat.gov.pl/obszary-tematyczne/edukacja/edukacja/dane-wstepne-dotyczace-szkolnictwa-wyzszego-2014-r-,8,2.html, 20 VI 2015.

16 Spośród wszystkich prowadzonych na polskich uczelniach kierunków do grupy studiów w zakresie stosunków międzynarodowych na przestrzeni lat 2000-2015 zaliczono: stosunki międzynarodowe, międzynarodowe stosunki gospodarcze, międzynarodowe stosunki polityczne, międzynarodową wspólpracę polityczną i gospodarczą, stosunki międzynarodowe i administrację. 
Należy zauważyć, że w analizowanym okresie widoczne jest podobieństwo losów politologii, stosunków międzynarodowych oraz europeistyki, gdzie wzrosty i spadki były bardzo szybkie, przy jednocześnie relatywnie niewielkich zmianach dla dziennikarstwa i komunikacji społecznej. Potwierdza to także analiza odsetka studentów tych kierunków studiów w stosunku do studentów w Polsce w ogóle. W przypadku politologii mówimy o spadku z poziomu 3,03\% w roku akademickim 2000/2001 do 0,71\% w roku akademickim 2014/2015, w przypadku stosunków międzynarodowych to spadek z 2,36\% w roku akademickim 2008/2009 do 1,08\% w roku 2014/2015, zaś dla europeistyki z $0,85 \%$ w roku akademickim $2008 / 2009$ do $0,33 \%$ w roku akademickim 2014/2015. Należy wyraźnie podkreślić, że populacja studentów na tych kierunkach studiów kurczy się dużo szybciej aniżeli liczba studentów w Polsce w ogóle. Inaczej przebiegają zmiany dla dziennikarstwa i komunikacji społecznej - tu także notujemy spadki, jednak dużo wolniejsze niż na wcześniej wskazywanych kierunkach. Gdy idzie natomiast o bezpieczeństwo, jakiekolwiek oceny są na razie przedwczesne. Rok akademicki 2014/2015 jest pierwszym, w którym zanotowano spadek liczby studentów, i na razie trudno powiedzieć, czy dalsze zmiany będą przebiegały podobnie do politologii i stosunków międzynarodowych, czy raczej do dziennikarstwa i komunikacji społecznej. Wiele przemawia niestety za pierwszym rozwiązaniem, o czym powiem więcej dalej. Szczegółowe dane prezentuje wykres 4.

Wykres 4. Odsetki studentów politologii oraz kierunków pokrewnych w stosunku do ogółu studentów w Polsce w latach 2000-2014

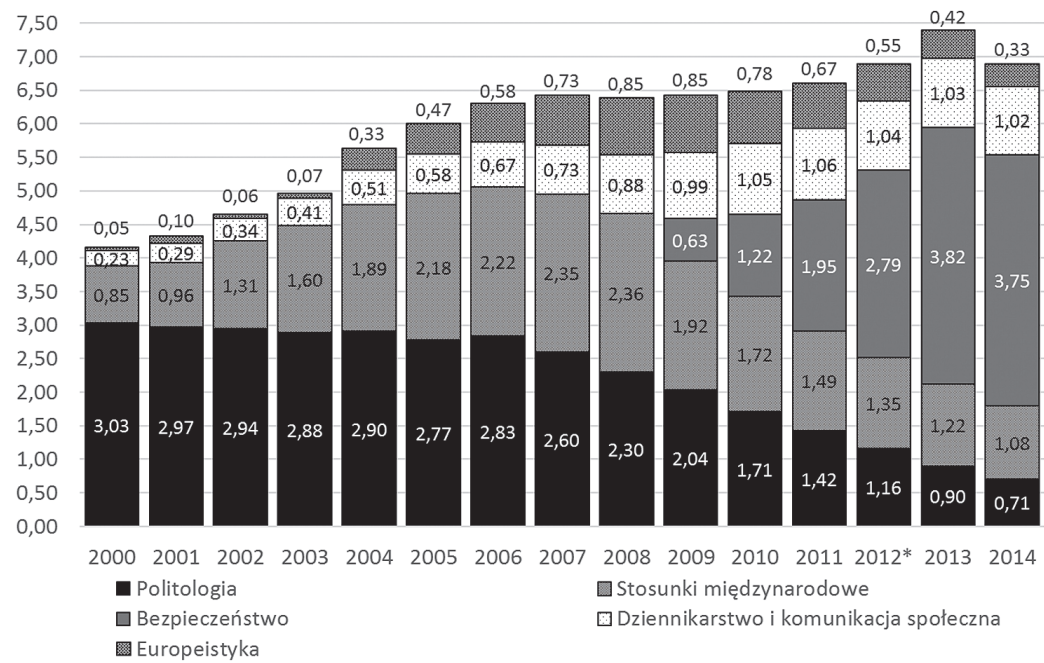

* Dane szacunkowe ze względu na brak danych dla roku 2012.

** Bezpieczeństwo narodowe, wewnętrzne, międzynarodowe + bezpieczeństwo jądrowe. Bezpieczeństwo w biznesie i administracji, bezpieczeństwo państwa, bezpieczeństwo narodowe i międzynarodowe.

Źródło: opracowanie własne na podstawie: Szkolnictwo wyższe. Dane podstawowe, Główny Urząd Statystyczny, Warszawa [2000-2011], Dane wstepne dotyczace szkolnictwa wyższego - 2013, [online] http:// stat.gov.pl/obszary-tematyczne/edukacja/edukacja/dane-wstepne-dotyczace-szkolnictwa-wyzszego-stan- 
-w-dniu-30-xi-2013-r-,8,1.html, 20 VI 2015; Dane wstępne dotyczace szkolnictwa wyższego - 2014, [online] http://stat.gov.pl/obszary-tematyczne/edukacja/edukacja/dane-wstepne-dotyczace-szkolnictwa-wyzszego-2014-r-,8,2.html, 20 VI 2015.

Na koniec tej części warto jeszcze powiedzieć, że spadkom liczby studentów na kierunku politologia oraz na kierunkach pokrewnych w ostatnich latach towarzyszył znaczący przyrost doktorów i doktorów habilitowanych w zakresie nauki o polityce. Dość powiedzieć, że w okresie pomiędzy kwietniem 2010 r. a czerwcem 2015 r. liczba zarejestrowanych w bazie Ośrodka Przetwarzania Informacji osób posiadających tytuł profesora lub stopień doktora habilitowanego w zakresie nauki o polityce wzrosła z 453 osób do 842 , a więc o blisko 400. Daje to średnio ok. 80 nowych pracowników samodzielnych każdego roku. Dla porównania w latach 90. XX w. nadawano średnio ok. 10 stopni doktora habilitowanego rocznie, zaś pod koniec pierwszego dziesięciolecia XXI w. ok. 2017. W latach 2010-2015 znacząco wzrosła również liczba doktorów - z 1566 do 2238, co daje średnio ok. 120 obron prac doktorskich rocznie. Dane szczegółowe prezentuje wykres 5 .

Wykres 5. Liczba politologów w Polsce w latach 2010-2015

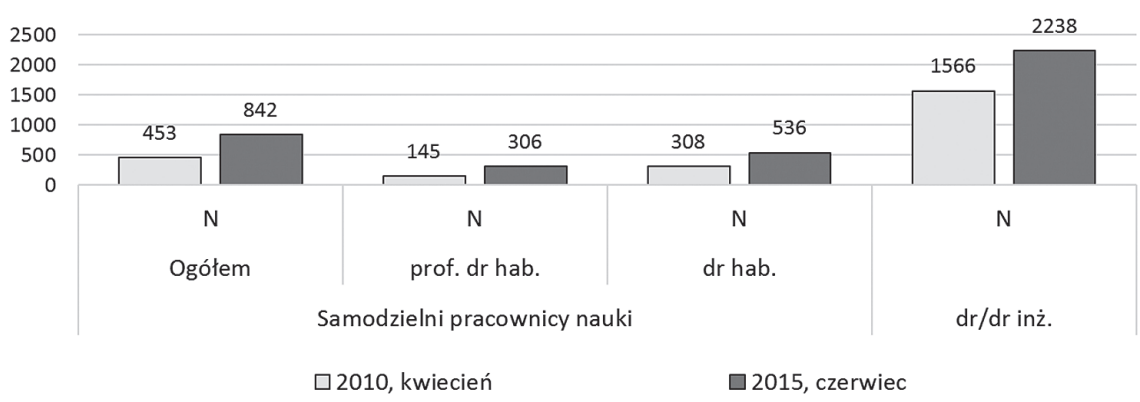

Źródło: dane dla roku 2010: B. Krauz-Mozer, P. Borowiec, P. Ścigaj, Kim jesteś, politologu? Historia i stan dyscypliny w Polsce, Kraków 2011, s. 212; dane dla roku 2015: http://www.nauka-polska.pl/dhtml/raportyWyszukiwanie/wyszukiwanieLudzieNauki.fs?lang=pl, 20 VI 2015.

Podsumujmy dotychczas przedstawione dane: po pierwsze, liczba studentów politologii w ostatnich 10 latach gwałtownie się kurczy, osiągając w roku akademickim 2014/2015 poziom ok. 10,5 tys., co odpowiada 0,71\% studentów w Polsce. Podobne procesy, choć o różnej sile i natężeniu, obserwuje się także na wybranych kierunkach pokrewnych, zwłaszcza na stosunkach międzynarodowych oraz europeistyce. Po drugie, tempo spadków zdaje się większe aniżeli dla ogółu studentów w Polsce, co może sugerować, że także czynniki odmienne od niżu demograficznego mogą w istotny sposób wpływać na kurczenie się zbiorowości studentów politologii oraz kierunków pokrewnych. Po trzecie, niepokojące wydaje się to, że w roku akademickim 2014/2015 także dla kierunku bezpieczeństwo zanotowano pierwszy raz spadek liczby studentów. Ze

17 B. Krauz-Mozer, P. Borowiec, P. Ścigaj, Kim jesteś, politologu?..., t. 1, s. 218. 
względu na fakt, że kierunki podejmujące problem bezpieczeństwa - rozmaicie ujmowanego - zostały otworzone w wielu jednostkach kształcących w zakresie politologii, owo zmniejszenie się liczby studentów może skutkować sporymi problemami, o czym powiem dalej. Po czwarte wreszcie, spadkom liczby studentów towarzyszy wzrost liczby osób ze stopniem naukowym doktora lub stopniem naukowym doktora habilitowanego w zakresie nauki o polityce.

\section{CO NAS CZEKA?}

Szacowanie wielkości populacji politologów w latach 2015-2020 wydaje się zadaniem trudnym ze względu na rozliczne czynniki, jakie powinny być brane pod uwagę. Nie ma potrzeby ich tutaj wszystkich wymieniać - nie jest to przecież artykuł na temat uwarunkowań funkcjonowania szkolnictwa wyższego w Polsce. Dość powiedzieć, że na potrzeby dalszych analiz przyjęto dwa kluczowe założenia: po pierwsze to, że nie ulegnie zmianie polityka państwa polskiego wobec szkolnictwa wyższego, a zwłaszcza nie zmienią się sposoby jego finansowania oraz najważniejsze uwarunkowania prawne; po drugie - nie nastąpią żadne nieprzewidywane w prognozach czynniki dodatkowe, które mogłyby odwrócić obecne trendy.

Jako punkt wyjścia dla prognoz przyjmuję wyliczenia MNiSW dotyczące zbiorowości studentów w kolejnych latach, które były cytowane wcześniej. Innymi słowy, zakładam, że w roku akademickim 2015/2016 będzie w Polsce ok. 1,5 mln studentów i liczba ta spadnie w roku 2020/2021 do ok. 1,3 mln studentów.

W dalszej części będę rozważał trzy scenariusze. Pierwszy z nich opiera się na przekonaniu, że popularność studiów politologicznych nie będzie dalej maleć, co znajdzie odzwierciedlenie w stałym i utrzymującym się przez kolejne lata odsetku studentów politologii w całej zbiorowości studentów w Polsce. Przypomnijmy, że w roku akademickim 2014/2015 odsetek ten wynosił 0,71\%. Co za tym idzie szacowanie liczby studentów politologii uwzględnia w tym scenariuszu stałą, gdy idzie o proporcję, wielkość populacji studentów politologii w Polsce, przy zmniejszającej się liczbie studentów. Szczegółowe dane prezentuje wykres 6.

Dwa pozostałe scenariusze przyjmują, że nie tylko liczba studentów Polsce w ogóle będzie się zmniejszać, ale zmianie ulegnie również wielkość grupy studentów politologii, a dokładnie: ona także będzie maleć. Dane zaprezentowane na wykresie 4 przekonują, że jest to nie tylko możliwe, ale i bardzo prawdopodobne. Przypomnijmy, że w szczytowym roku akademickim ostatniego piętnastolecia blisko co 30 student w Polsce odbierał swoją edukację na kierunku politologia (3,03\% studentów w Polsce w roku akademickim 2000/2001). Przez kolejne lata odsetek studentów politologii w ogólnej liczbie studentów malał, a zmiana ta była szczególnie szybka po roku 2006. Mając to na względzie, zakładam, że tendencja ta będzie dalej widoczna. Powody takiego przekonania są następujące: po pierwsze, wiele wskazuje na to, że kandydaci na studia w zakresie politologii traktują ją często jako kierunek drugiego wyboru. Wraz ze zmniejszającą się liczbą kandydatów będącą konsekwencją niżu demograficznego zwiększą się moż- 
liwości wielu osób na otrzymanie indeksu na innym kierunku studiów, traktowanym jako bardziej atrakcyjny (np. prawo). Po drugie, politologia nie rywalizuje o studentów jedynie z kierunkami o mocnej i ugruntowanej pozycji na rynku edukacyjnym, ale także z rozlicznymi kierunkami pokrewnymi. Wiele wskazuje na to, że grupa kandydatów pragnących studiować szeroko pojęte "nauki polityczne” (przez co rozumiem także kierunki, na których naucza się powszechnie o rozmaitych odsłonach zjawisk politycznych, np. stosunki międzynarodowe, pewne formy bezpieczeństwa, europeistyka, dziennikarstwo i komunikacja społeczna, studia nad regionami świata itp.) jest raczej podobna każdego roku. Zmniejsza się ona, rzecz jasna, lecz pozostaje względnie stała, gdy idzie o odsetek studentów w Polsce. Jeśli zgodzimy się z tym przekonaniem, to jednym z ważnych czynników zmniejszania się zainteresowania studiami politologicznymi może być konkurencja z kierunkami pokrewnymi. Po trzecie, politologia w dalszym ciągu zdaje się być postrzegana jako kierunek nieprzydatny na rynku pracy, wręcz „toksyczny”, który „produkuje bezrobotnych”. Nie zamierzam w tym miejscu podejmować polemiki z tym niesprawiedliwym i nieprawdziwym sądem ${ }^{18}$. Dość uznać, że wykorzystywanie w debacie medialnej przez pewien czas politologii jako przykładu „złego” wykształcenia będzie, moim zdaniem, jeszcze wiele lat rzutowało na nie najlepszy odbiór tego kierunku studiów. Po czwarte wreszcie, znaczne spadki liczby studentów politologii, zwłaszcza zmniejszanie się odsetka studentów politologii w ogóle studentów w Polsce, mogą być (i najpewniej są) związane z wygaszaniem tego kierunku studiów na części uczelni. Wraz z kryzysem naboru i radykalnym spadkiem liczby kandydatów ${ }^{19}$ część jednostek kontynuuje rozpoczęte kilka lat temu programy, co oznacza, że zbiorowość studentów politologii na tych uczelniach się w ogóle nie odtwarza, lub otwiera nowe kierunki o podobnym charakterze, jednak unikając nazwy „politologia”. O ile więc w niektórych szkołach wyższych notuje się spadek naboru i uruchamia mniejsze roczniki, o tyle w innych jedynie dokańcza się rozpoczęte jakiś czas temu cykle kształ-

18 Argumenty przeciwko temu niesłusznemu przekonaniu były już wielokrotnie przedstawiane. Zob. np.: tamże, s. 206-210; M. Karwat, Politolog - premierowi, „Dziennik Trybuna” 2013, nr 75, s. 10-11, [online] http://www.home.umk.pl/ ptnp/do_pobrania/ROZNE/MK_Politolog\%20_premierowi_ DT.pdf, 1 VII 2015; K.B. Janowski, Czy hamletyzować... „spawacz «or» politolog”?, [online] http:// www.home.umk.pl/ ptnp/do_pobrania/ROZNE/Czy\%20hamletyzowac._.\%20spawacz\%20 czy\%20politolog.pdf, 6 VII 2015; Ł. Młyńczyk, „Nagty atak spawaczem”, [online] http://www.home. umk.pl/ ptnp/do_pobrania/ROZNE/Lukasz_Mlynczyk_Dyskusje.pdf, 4 VII 2015; Stanowisko delegatów Zjazdu Polskiego Towarzystwa Nauk Politycznych w sprawie doniesień prasowych nt. wystąpień Premiera RP Donalda Tuska nawiązujących do miejsca absolwentów politologii na rynku pracy w Polsce, [online] http://www.home.umk.pl/ p ptnp/do_pobrania/ROZNE/Stanowisko_ZPTNP.pdf, 6 VII 2015; Ślusarze z Kurzętnika, z prof. Romanem Bäckerem rozmawia Adam Wilma, „Gazeta Pomorska" 2013, 6 IX.

19 Zgodnie z danymi publikowanymi przez MNiSW największe zainteresowanie studiami politologicznymi miało miejsce w latach 2003-2006, kiedy co roku notowano ok. 28 tys. rejestracji kandydatów na kierunek. Po roku 2006 liczba ta zaczęła szybko spadać, aż do poziomu 15347 w roku akademickim 2009/2010. Od tego czasu MNiSW nie przekazuje informacji na temat kandydatów na politologię, co oznacza, że jest ich w każdym roku mniej niż 10 tys., albowiem tylko dla kierunków notujących więcej niż 10 tys. zgłoszeń dane są podawane. B. Krauz-Mozer, P. Borowiec, P. Ścigaj, Political Science in Poland..., s. 24. 
cenia, a nie uruchamia się już nowych ze względu na brak chętnych. Biorąc pod uwagę powyższe kwestie, przyjmuję, że odsetek studentów politologii w ogóle studentów w Polsce będzie dalej się zmniejszać. Tempo tego spadku może być jednak różne, co jest podstawą dwóch kolejnych scenariuszy.

W przypadku pierwszym zakładam, że odsetek studentów politologii w ogóle studentów w Polsce będzie dalej malał, jednak wolniej niż do tej pory. Wydaje się to całkiem prawdopodobne, tym bardziej że w ostatnich pięciu latach zaobserwować już można pewne symptomy wyhamowywania tempa spadku liczby studentów politologii. Przyjmuję więc - arbitralnie - dla potrzeb prognozy, że w każdym kolejnym roku akademickim ów odsetek będzie mniejszy o 90\%. Innymi słowy, o ile w roku akademickim 2014/2015 wynosił on $0,71 \%$ ogółu studentów w Polsce, o tyle w roku akademickim 2015/2016 będzie to 0,64\%, zaś w kolejnych latach: 0,57\% - 2016/2017, 0,52\% $2017 / 2018,0,46 \%-2018 / 2019,0,42 \%-2019 / 2020$ oraz 0,38\% - 2020/2021. Takie założenia są podstawą obliczeń w scenariuszu drugim.

W kolejnym scenariuszu przyjmuję, że liczba studentów politologii w każdym kolejnym roku akademickim będzie każdorazowo równa 77\% liczby studentów w roku poprzedzającym. Proporcja ta stanowi uśrednioną wartość wysokości spadków zbiorowości studentów politologii w latach 2010-2014. Stanowi ona więc podstawę szacowania liczby studentów politologii w scenariuszu trzecim. Wyniki dla wszystkich trzech scenariuszy prezentuje wykres 6 .

Wszystkie scenariusze przewidują dalsze spadki liczby studentów politologii w Polsce. W wariancie pierwszym w roku akademickim 2020/2021 nieco ponad 9 tys. osób będzie odbierało edukację na kierunku politologia. Jeśliby tak się stało, to przyszłe lata należałoby rozpatrywać w kategoriach trwania obecnej sytuacji naboru wielu jednostek. To może być okres stabilny i bezpieczny dla wielu uczelni, albowiem o ile dalsze spadki będą widoczne, o tyle ich tempo może prowadzić do ostrożnego przekonania, że to, co najgorsze - jest już za nami.

Jak wspominałem wcześniej, uważam ten scenariusz za mało prawdopodobny, by nie powiedzieć - niemożliwy. Daleko bardziej realne wydają mi się scenariusze drugi i trzeci. Procesy opisane wcześniej, które mogą mieć wpływ na siłę spadków liczby studentów politologii, nie znikną natychmiast i będą z pewnością w dalszym ciągu miały negatywne skutki dla naboru na studia. Zgodnie z drugim scenariuszem w roku 2020/2021 w Polsce będzie nieco mniej niż 5 tys. studentów politologii. Według trzeciego scenariusza będzie to mniej niż 2,2 tys. Jeśli przewidywania te okażą się trafne, to za pięć lat wrócimy do poziomu liczby studentów z początku lat 90 . ubiegłego stulecia, a nawet przebijemy ją - w dół! Jestem przekonany, że realna wielkość zbiorowości studentów politologii będzie mieściła się pomiędzy tymi dwiema wartościami - między 5 tys. a 2,2 tys. Bez względu jednak na ostateczny wynik czekają nas najpewniej lata niezmiernie trudne, a dla wielu jednostek wręcz krytyczne.

Warto jeszcze rozważyć, jaka przyszłość czeka kierunki pokrewne dla politologii, przy zastrzeżeniu, że stosujemy wobec nich takie same założenia, jak w przypadku prognoz wcześniejszych. I tak, w przypadku scenariusza pierwszego, zakładającego stały i niezmienny odsetek studentów kierunków pokrewnych w zbiorowości studentów 
w Polsce, liczba studentów bezpieczeństwa zmniejszy się z 55122 w roku akademickim 2014/2015 do 47633 w roku 2020/2021, grupa studiujących dziennikarstwo i komunikację społeczną zmniejszy się w analogicznym okresie z 14938 do 13 311, studiujących europeistykę ubędzie z poziomu 4908 do 4307, zaś liczba studentów stosunków międzynarodowych spadnie z 15873 do 14094 .

Wykres 6. Prognoza liczby studentów politologii w latach 2015-2020

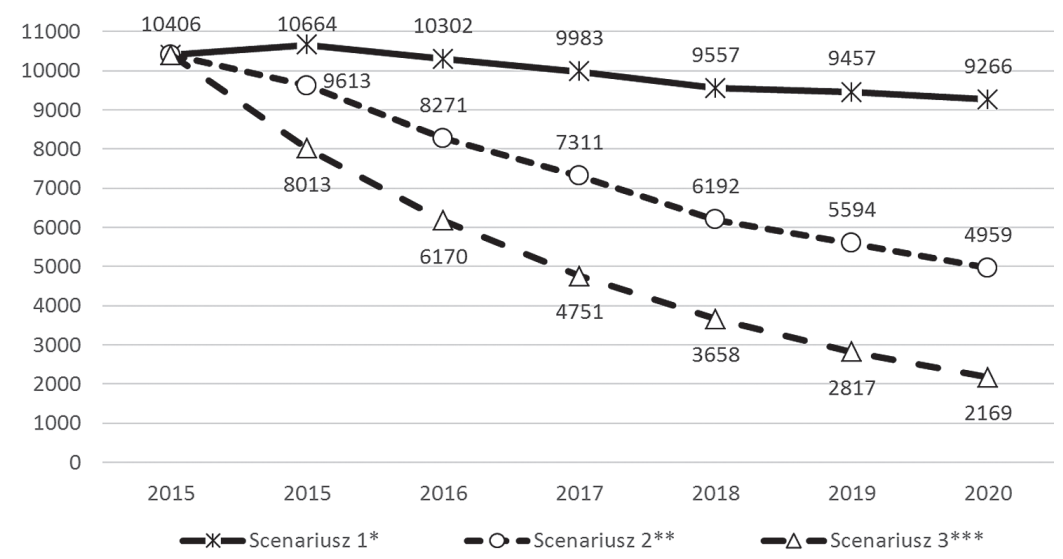

* Scenariusz 1: proporcja studentów politologii wobec studentów w Polsce w ogóle - stała, na poziomie $0,71 \%$.

** Scenariusz 2: proporcja studentów politologii wobec studentów w Polsce w ogóle - zmienna, na poziomie: $2015 / 2016$ - 0,64\%, 2016/2017 - 0,57\%, 2017/2018 - 0,52\%, 2018/2019 - 0,46\%, 2019/2020 $0,42 \%, 2020 / 2021-0,38 \%$.

*** Scenariusz 3: liczba studentów politologii w każdym roku akademickim na poziomie $77 \%$ populacji z roku uprzedniego.

Źródło: opracowanie własne na podstawie: Szkolnictwo wyższe w Polsce, 2013, Ministerstwo Nauki i Szkolnictwa Wyższego, s. 8, [online] http://www.nauka.gov.pl/g2/oryginal/2013_07/0695136d37bd577c8ab03acc5c59a1f6.pdf, 2 VII 2015.

Ten scenariusz wydaje mi się jednak, podobnie jak w przypadku politologii, również mało prawdopodobny. Jak już wspominałem, kierunki te doświadczają podobnych problemów co politologia, choć w różnym stopniu. W większym stopniu dotykają one stosunki międzynarodowe, europeistykę, a w przyszłości dotyczyć będą - o czym jestem przekonany - bezpieczeństwa. W mniejszym stopniu odnoszą się one do dziennikarstwa i komunikacji społecznej. Pamiętając o tym, warto pokusić się o próbę prognozy dla dwóch pesymistycznych scenariuszy dla tych kierunków studiów, przy założeniach takich samych jak dla politologii. Dane oraz założenia obliczeń prezentuje tab. 2.

Powyższe przewidywania rysują przyszłość kierunków pokrewnych dla politologii w Polsce w ciemnych barwach. Wyjątkiem jest jedynie dziennikarstwo i komunikacja społeczna, gdzie spadki powinny być najmniejsze. Natomiast perspektywa rozwojowa stosunków międzynarodowych oraz europeistyki nie jest najlepsza. Oba scenariusze przewidują dla tych kierunków studiów intensywne spadki, prowadzące do niebez- 
pieczeństw, jakie przeżywamy w przypadku politologii. Najlepiej w tym kontekście wypadają kolejne lata dla kierunku bezpieczeństwo, choć i tu liczba studentów będzie maleć. Oczywiście przewidywania w tym wypadku są szczególnie narażone na błędy, albowiem liczba studentów na bezpieczeństwie po raz pierwszy spadła dopiero w roku akademickim 2014/2015. Nie możemy więc mówić o żadnym trendzie spadkowym - na razie to jednorazowa zmiana. Niemniej losy innych pokrewnych kierunków - zwłaszcza politologii i stosunków międzynarodowych - przekonują, że przyszłość bezpieczeństwa może być podobna, zwłaszcza na uczelniach cywilnych, gdzie kierunek ten nie jest prowadzony w ścisłym związku z możliwością podjęcia pracy w strukturach mundurowych. Dlatego też sądzę, że zmniejszająca się liczba studentów bezpieczeństwa w roku akademickim 2014/2015 to dopiero początek gwałtownego trendu spadkowego.

Tabela 2. Prognoza liczby studentów kierunków pokrewnych dla politologii w latach 2015-2020

\begin{tabular}{|c|c|c|c|c|c|c|c|c|}
\hline \multirow[t]{2}{*}{$\begin{array}{c}\text { Rok } \\
\text { akademicki }\end{array}$} & \multicolumn{2}{|c|}{ Bezpieczeństwo } & \multicolumn{2}{|c|}{$\begin{array}{c}\text { Dziennikarstwo } \\
\text { i komunikacja } \\
\text { społeczna }\end{array}$} & \multicolumn{2}{|c|}{ Europeistyka } & \multicolumn{2}{|c|}{$\begin{array}{c}\text { Stosunki } \\
\text { międzynarodowe }\end{array}$} \\
\hline & $S 2^{a}$ & $\mathrm{~S} 3^{\mathrm{b}}$ & $S 2^{c}$ & $\mathrm{~S} 3^{\mathrm{d}}$ & $S 2^{\mathrm{c}}$ & $S 3^{f}$ & $S 2^{g}$ & $S 3^{\mathrm{h}}$ \\
\hline $2015 / 16$ & 50768 & 51263 & 15020 & 14340 & 4506 & 3877 & 14569 & 13492 \\
\hline $2016 / 17$ & 44110 & 47675 & 14220 & 13767 & 3918 & 3063 & 12769 & 11468 \\
\hline $2017 / 18$ & 38384 & 44338 & 13498 & 13216 & 3374 & 2420 & 11107 & 9748 \\
\hline $2018 / 19$ & 33112 & 41234 & 12652 & 12688 & 2961 & 1912 & 9557 & 8286 \\
\hline $2019 / 20$ & 29570 & 38348 & 12254 & 12180 & 2664 & 1510 & 8525 & 7043 \\
\hline $2020 / 21$ & 25970 & 35663 & 11745 & 11693 & 2349 & 1193 & 7439 & 5986 \\
\hline
\end{tabular}

S 2 - Scenariusz 2; S 3 - Scenariusz 3.

a - Proporcja studentów wobec studentów w Polsce w ogóle - zmienna, na poziomie: 2015/2016 - 3,38\%, 2016/2017 - 3,04\%, 2017/2018 - 2,73\%, 2018/2019 - 2,46\%, 2019/2020 - 2,22\%, 2020/2021 - 1,99\%.

b - Liczba studentów w każdym roku akademickim na poziomie $93 \%$ populacji z roku uprzedniego, co jest równe wartości spadku liczby studentów w roku 2014/2015 do roku uprzedniego.

c - Proporcja studentów wobec studentów w Polsce w ogóle - zmienna, na poziomie: 2015/2016 - 1,00\%, 2016/2017 - 0,98\%, 2017/2018 - 0,96\%, 2018/2019 - 0,94\%, 2019/2020 - 0,92\%, 2020/2021 - 0,90\%.

d - Liczba studentów w każdym roku akademickim na poziomie $96 \%$ populacji z roku uprzedniego, co jest uśrednioną z lat 2010-2014 wartością spadku liczby studentów danego kierunku.

c - Proporcja studentów wobec studentów w Polsce w ogóle - zmienna, na poziomie: 2015/2016 - 0,30\%, 2016/2017 - 0,27\%, 2017/2018 - 0,24\%, 2018/2019-0,22\%, 2019/2020 - 0 20\%, 2020/2021 - 0,18\%.

f - Liczba studentów w każdym roku akademickim na poziomie 79\% populacji z roku uprzedniego, co jest uśrednioną z lat 2010-2014 wartością spadku liczby studentów danego kierunku.

$\mathrm{g}$ - Proporcja studentów wobec studentów w Polsce w ogóle - zmienna, na poziomie: 2015/2016 - 0,97\%, 2016/2017 - 0,88\%, 2017/2018 - 0,79\%, 2018/2019-0,71\%, 2019/2020 - 0,64\%, 2020/2021 - 0,57\%.

h - Liczba studentów w każdym roku akademickim na poziomie $85 \%$ populacji z roku uprzedniego, co jest uśrednioną z lat 2010-2014 wartością spadku liczby studentów na kierunku.

Źródło: opracowanie własne na podstawie: Szkolnictwo wyższe w Polsce, 2013, Ministerstwo Nauki i Szkolnictwa Wyższego, s. 8, [online] http://www.nauka.gov.pl/g2/oryginal/2013_07/0695136d37bd577c8ab03acc5c59a1f6.pdf, 2 VII 2015. 


\section{WNIOSKI}

Przedstawione w tym artykule dane oraz prognozy nie napawają optymizmem. Już blisko 10 lat temu politologia weszła w fazę kryzysu naboru na studia i nie wydaje się, aby w kolejnych latach zdołała z niego wyjść. Podobnie niestety dzieje się na kierunkach pokrewnych, co jest o tyle istotne, że są one nierzadko prowadzone przez te same jednostki, które oferują także studia w zakresie politologii. I o ile, jak się zdaje, europeistyka, dziennikarstwo i komunikacja społeczna, stosunki międzynarodowe czy bezpieczeństwo (jak i inne kierunki studiów) mogły umożliwiać dalszy rozwój niektórych jednostek politologicznych, w tym utrzymanie kadry naukowo-dydaktycznej oraz infrastruktury, o tyle w kolejnych latach „źródła” te mogą wyschnąć.

Jakie będą tego skutki? Przede wszystkim nieuruchamianie kierunków studiów w wielu jednostkach prowadzące do ich wygaszania, a nawet likwidacji jednostek naukowo-dydaktycznych. Widzimy to już dziś. Niestety w kolejnych latach procesy te nasilą się. Jednocześnie tendencje wzrostowe w zakresie liczby nadań stopnia doktora i doktora habilitowanego w naukach o polityce sprawią, że pojawi się wielu nowych specjalistów. Duża część z nich nie będzie jednak mogła podjąć, a niekiedy również kontynuować pracy na uczelni wyższej ze względu na brak studentów i kierunku studiów. Wielu wykwalifikowanych politologów ze stopniami naukowymi może trafić na rynek pracy, gdzie będą zmuszeni rywalizować o dostęp do satysfakcjonujących zawodów.

Na koniec warto jeszcze przytoczyć trafne słowa Jarosława Górniaka:

Sytuacja demograficzna stawia zatem szkolnictwo wyższe przed strukturalnymi wyzwaniami, a przed Ministerstwem Nauki i Szkolnictwa Wyższego stawia zadanie przemyślenia strategii rozwoju sektora. Nowa sytuacja niesie ryzyko, ale też rodzi szanse poprawy jakości ksztatcenia i wzmocnienia badań naukowych. Gtówna trudnościa stana sie napięcia strukturalne wynikające z tego, że kluczowym beneficjentem środków na badania będa dyscypliny (uczelnie, wydziaty), które w mniejszym stopniu ulegty koniunkturalnej ekspansji i nie maja aż tak dużych problemów ze spadkiem liczby studentów, jak zwtaszcza nauki spoteczne (z ekonomicznymi) i humanistyczne. Kryzys humanistyki zostatjuż „otrabiony", lecz czasy jeszcze trudniejsze sa przed nami. Czy ten segment znajdzie swoja droge do dywersyfikacji i przynajmniej częściowego uniezależnienia swojej egzystencji od dotacji dydaktycznej i czesnego? Nie będzie to tatwe przedsięwzięcie ${ }^{20}$.

Wiele wskazuje na to, że największe problemy są jeszcze przed nami. Warto się do nich przygotować i starać się im przeciwdziałać, choć to na pewno nie będzie łatwe przedsięwzięcie.

20 J. Górniak, Ogólne uwarunkowania sytuacji szkolnictwa wyższego w Polsce, [w:] Diagnoza szkolnictwa wyższego. Program rozwoju szkolnictwa wyższego do 2020, cz. 3, red. tenże, Warszawa 2015, s. 34, [online] http://www.frp.org.pl/publikacje/cz_III_PROGRAM_001244_Diagnoza.pdf, 2 VII 2015. 


\section{BIBLIOGRAFIA}

Antonowicz D., Gorlewski B., Demograficzne tsunami. Raport Instytutu Sokratesa na temat wptywu zmian demograficznych na szkolnictwo wyższe do 2020 roku, Warszawa 2011, [online] http://instytutsokratesa.pl/pliki/Demograficzne_Tsunami_Instytut_Sokratesa.pdf.

Diagnoza stanu szkolnictwa wyższego w Polsce, Raport cząstkowy przygotowany przez konsorcjum Ernst\&Young Business Advisory oraz Instytut Badań nad Gospodarką Rynkową, listopad 2009, [online] http://www.nauka.gov.pl/g2/oryginal/2013_05/fa5b19 e372elbed45db817b8380c8468.pdf.

Górniak J., Ogólne uwarunkowania sytuacji szkolnictwa wyższego w Polsce, [w:] Diagnoza szkolnictwa wyższego. Program rozwoju szkolnictwa wyższego do 2020, cz. 3, red. tenże, Warszawa 2015, [online] http://www.frp.org.pl/publikacje/cz_III_PROGRAM_001244_Diagnoza.pdf.

Higher Education to 2030, vol. 1: Demography, OECD Publishing, 2008, [online] http://www. oecd.org/edu/ceri/41939423.pdf.

Informacja o wynikach rekrutacji na studia na rok akademicki 2012/2013 w uczelniach nadzorowanych przez Ministra Nauki i Szkolnictwa Wyższego, [online] https://www.nauka.gov.pl/ g2/oryginal/2013_11/01e458dfe708774d43130e085402f03a.doc.

Informacja o wynikach rekrutacji na studia na rok akademicki 2013/2014 w uczelniach nadzorowanych przez Ministra Nauki i Szkolnictwa Wyższego, [online] http://www.nauka.gov.pl/ g2/oryginal/2013_05/2c9dcb54750b1bea5b1e3c22cad6f20a.pdf.

Informacja o wynikach rekrutacji na studia na rok akademicki 2014/2015 w uczelniach nadzorowanych przez Ministra Nauki i Szkolnictwa Wyższego, [online] http://www.nauka.gov.pl/ g2/oryginal/2014_11/b34c7353d34b2c9a42ee14aa2b005e27.pdf.

Janowski K.B., Czy hamletyzować... „spawacz «or» politolog”?, [online] http://www.home.umk. $\mathrm{pl} /$ ptnp/do_pobrania/ROZNE/Czy\%20hamletyzowac._.\%20spawacz\%20czy\%20politolog.pdf.

Karwat M., Politolog - premierowi, „Dziennik Trybuna” 2013, nr 75, [online] http://www. home.umk.pl/ ptnp/do_pobrania/ROZNE/MK_Politolog\%20_premierowi_DT.pdf.

Krauz-Mozer B., Borowiec P., Scigaj P., The Condition and Perspectives of Political Science in the Beginning of the 21st Century, [w:] Political Science in Europe at the Beginning of the 21st Century, red. B. Krauz-Mozer i in., Kraków 2015 [w druku].

Krauz-Mozer B., Borowiec P., Ścigaj P., Kim jesteś, politologu? Historia i stan dyscypliny w Polsce, t. 1-2, Kraków 2011-2012.

Krauz-Mozer B., Borowiec P., Ścigaj P., Political Science in Poland within 1989-2009. Applicants, Students and Graduates of Political Studies, „Athenaeum” 2011, nr 30.

Młyńczyk Ł., „Nagty atak spawaczem”, [online] http://www.home.umk.pl/ ptnp/do_pobrania/ROZNE/Lukasz_Mlynczyk_Dyskusje.pdf.

Stanowisko delegatów Zjazdu Polskiego Towarzystwa Nauk Politycznych w sprawie doniesień prasowych nt. wystąpień Premiera RP Donalda Tuska nawiązujacych do miejsca absolwentów politologii na rynku pracy $w$ Polsce, [online] http://www.home.umk.pl/ ptnp/do_pobrania/ ROZNE/Stanowisko_ZPTNP.pdf. 
Strategia rozwoju szkolnictwa wyższego 2010-2020. Projekt środowiskowy, Warszawa 2009, [online] http://www.krasp.org.pl/pliki/fdc2bf4809b691e28546a48f8451c42f.pdf.

Strategia rozwoju szkolnictwa wyższego w Polsce do 2020 roku - drugi wariant, Raport cząstkowy przygotowany przez konsorcjum Ernst\&Young Business Advisory oraz Instytut Badań nad Gospodarką Rynkową, marzec 2010, [online] http://www.nauka.gov.pl/g2/orygina1/2013_05/59579f9 e6efaec82014d6d5be081ca23.pdf.

Szkolnictwo wyższe w Polsce, 2013, Ministerstwo Nauki i Szkolnictwa Wyższego, [online] http:// www.nauka.gov.pl/g2/oryginal/2013_07/0695136d37bd577c8ab03acc5c59alf6.pdf.

Szkoty wyższe i ich finanse w 2013 roku, Główny Urząd Statystyczny, Warszawa 2014.

Ślusarze z Kurzętnika, z prof. Romanem Bäckerem rozmawia Adam Wilma, „Gazeta Pomorska” 2013, 6 IX.

Dr Paweł ŚCIGAJ - adiunkt w Zakładzie Teorii Polityki i Państwa w Instytucie Nauk Politycznych i Stosunków Międzynarodowych Uniwersytetu Jagiellońskiego. Autor monografii Tożsamość narodowa. Zarys problematyki (2012), współautor monografii Kim jesteś, politologu? Historia i stan dyscypliny w Polsce, t. 1-2 (2-11-2012). Współredaktor prac Szkice o pograniczach nauki (2007), Podejścia badawcze i metodologie w nauce o polityce (2013), Odmiany wspótczesnej nauki o polityce, t. 1-2 (2014). Autor około trzydziestu artykułów z zakresu socjologii polityki, teorii polityki, psychologii polityki i metodologii nauk społecznych. 